\title{
TGF- $\beta 1$ level in platelet-rich plasma in patients with diseases and injuries of the musculoskeletal system
}

\author{
Goliuk Ye. ${ }^{1}$, Yavorovska V. ${ }^{2}$, Bezdeneznykh N. ${ }^{3}$, Kozak T. ${ }^{3}$, Saulenko K. ${ }^{1}$ \\ ${ }^{1}$ The Scientific and Practice Center of Tissue and Cellular Therapy, State Institute of Traumatology and Orthopedics of the \\ National Academy of Medical Sciences of Ukraine, Kyiv, Ukraine \\ ${ }^{2}$ Palladin Institute of Biochemistry of the National Academy of Sciences of Ukraine, Kyiv, Ukraine \\ ${ }^{3}$ Kavetsky Institute of Experimental Pathology, Oncology and Radiobiology of the National Academy of Sciences of Ukraine, \\ Kyiv, Ukraine \\ e-mail: viyavr@gmail.com
}

\section{ABSTRACT}

Platelet-rich plasma (PRP) is plasma with high concentration of platelets compared with whole blood. The therapeutic effect of platelet-rich plasma is based on the effect of growth factors contained in a-granules of platelets. Transforming growth factor $\beta 1$ (TGF- $\beta 1)$ is a growth factor of TGF- $\beta$ superfamily which an amount is considerable in platelets and have the important role in musculoskeletal system regeneration.

MATERIALS AND METHODS. In this study using the ELISA, we determined the content of TGF- $\beta 1$ in platelet-rich plasma in 14 patients with various musculoskeletal disorders, aged from 21 to 79.

RESULTS. The level of TGF- $\beta 1$ in platelet-rich plasma was found to be $194.57 \pm 25.76 \mathrm{ng} / \mathrm{ml}$, which was 30 times higher than its control content (platelet-poor plasma), where its content was $6.52 \pm 3.26 \mathrm{ng} / \mathrm{ml}$. No statistically significant difference was observed between TGF- $\beta 1$ levels in platelet-rich plasma in the patients of different age and gender.

CONCLUSIONS. It has been established that platelet-rich plasma can serve as a source of TGF- $\beta 1$ for therapeutic purposes. TGF- $\beta 1$ content in platelet-rich plasma has been shown to be independent of gender and age and, therefore, a wide range of patients may be treated with it.

KEY WORDS: platelet-rich plasma; TGF- $\beta 1$; diseases of the musculoskeletal system

Platelet-rich plasma (PRP) is plasma with high platelet count. Currently, PRP is used in many fields of medicine $[1,2,9]$. It is believed that the platelet count in PRP should be about 1 million per $1 \mu \mathrm{l}$, or 2-5 times higher than in whole blood of a healthy person, where their content is 150,000 to 450,000 per $1 \mu \mathrm{l}$. This platelet concentration is considered necessary for effective tissue regeneration. PRP is usually obtained from the patient's own blood (autologous PRP) [10].

There are many methods and techniques to obtain PRP $[18,21]$, which significantly complicates the development of its classification. The most commonly used classification is developed by D. Dohan Ehrenfest, who divided platelet concentrates by leukocyte concentration and fibrin content into 4 groups [11]. According to this classification, PRP is divided by the content of leukocytes into leukocyte-containing and pure. Leukocyte-containing PRP has a high concentration of leukocytes, pure PRP is characterized by their low content. Other classifications of platelet concentrates have been proposed, in particular by J. Magalon. It uses the number of platelets, the percentage of platelets and other cells in PRP. This classification takes into account the effectiveness of techniques and devices for platelet isolation [20].
Although PRP is used in many fields of medicine $[3,12]$, the mechanisms of its action have not been completely studied yet. It is believed that the therapeutic effect of PRP is due to the action of intracellular growth factor proteins contained in platelet a-granules. Growth factors stimulate cell proliferation and migration in damaged tissue, accelerating the regeneration $[5,14,13]$.

Transforming growth factor $\beta 1$ (TGF- $\beta 1$ ) is one of the growth factors abundantly present in platelets $[25,15]$. TGF- $\beta 1$ belongs to the cytokine of TGF- $\beta$ superfamily, which plays an important role in the regeneration of musculoskeletal tissues. It participates in all stages of cartilage development, promotes differentiation, proliferation of chondroblasts and synthesis of extracellular matrix molecules, such as type II collagen and proteoglycans $[6,17,19,24,23]$. In addition, TGF- $\beta 1$ is involved in the proliferation of tendon fibroblasts and their synthesis of the extracellular matrix, in particular type I collagen $[8,16]$. It also participates in the remodeling of the bone tissue, contributing to the fracture consolidation [7, 22].

The PURPOSE of the study was to determine the level of TGF- $\beta 1$ in platelet-rich plasma in patients with various disorders of the musculoskeletal system. 


\section{MATERIALS AND METHODS}

Autologous biotechnological products of the blood of 14 patients with various diseases and injuries of the musculoskeletal system became the material for the study. Patients had exclusively local pathology of the musculoskeletal system, without systemic concomitant diseases, so this sample can be considered homogeneous. The distribution of patients by types of pathology is given in table. 1. There were 7 women and 7 men aged 21 to 79 years among them, at the average age of $49 \pm 22$ years. The study involved women aged 21 to 79 years (average age $52 \pm 25$ years) and men aged 25-77 years (average age $48 \pm 20$ years). The patients provided an informed consent to the study.

To prepare PRP, we performed the sampling of $50 \mathrm{ml}$ venous blood in vacuum tubes with anticoagulant citrate dextrose. Blood sampling was performed fasting. A week before blood sampling, non-steroidal antiinflammatory drugs were discontinued, patients were assigned a special diet (exclusion of fatty, fried and spicy foods, fluid intake up to 3 liters per day, exclusion of coffee) and regimen (refusal of smoking and alcohol).

The blood was centrifuged at $250 \mathrm{xg}$ for $10 \mathrm{~min}$ to separate plasma and blood cells using a centrifuge CM-3 (MICROmed, China). Thereafter, the plasma was transferred to new tubes and centrifuged at $2300 \mathrm{xg}$ for $5 \mathrm{~min}$. The pellet containing platelets was resuspended in $3 \mathrm{ml}$ plateletpoor plasma (PPP) [4]. Platelet-poor plasma (PPP) obtained from the second plasma centrifugation was used as a control. $500 \mu \mathrm{l}$ samples of PRP and PPP were frozen and stored at $-20^{\circ} \mathrm{C}$.

For enzyme-linked immunosorbent assay (ELISA), the samples of PRP and PPP were thawed at room temperature and were centrifuged at $250 \mathrm{xg}$ for $10 \mathrm{~min}$. The supernatant was used to further study using the TGF- $\beta 1$ ELISA kit (DRG International, Inc., USA) according to the manufacturer's instructions. Optical density measurements were performed on a microplate reader Synergy HT SIAFRTD (Bio-Tek Instruments, USA) at a wavelength of $450 \mathrm{~nm}$. According to the optical density of standards with known concentrations of TGF- $\beta 1$, a calibration curve was designed, according to which the content of TGF- $\beta 1$ in $\mathrm{ng} / \mathrm{ml}$ was calculated.

The variables of experimental data were determined by descriptive statistics and are presented as mean \pm standard deviation. The Student's t-test was used as the criterion for the significance of differences between the groups. The differences were considered as statistically significant at $p<0.05$. Statistical analysis of the data was performed using Excel statistics software (Microsoft, USA).

\section{RESULTS AND DISCUSSION}

The content of TGF- $\beta 1$ was determined by ELISA in 23 samples of PRP obtained from 14 patients with various pathologies of the musculoskeletal system (Table 1). The blood of each patient as a donor was used to prepare from 1 to 3 PRP products without taking into account the pathology of the musculoskeletal system, age and gender.

It was determined that the average level of TGF- $\beta 1$ in PRP samples was $194.57 \pm 25.76 \mathrm{ng} / \mathrm{ml}$ compared to the control PPP group, where its content was $6.52 \pm 3.26 \mathrm{ng} / \mathrm{ml}$ (Fig. 1). Accordingly, the level of TGF- $\beta 1$ in the PRP was 30 times higher than in control PPP.

TGF- $\beta 1$ plays a key role at all stages of chondrogenesis [24] and is therefore considered as a potential therapeutic agent for osteoarthritis

Table 1. Individual parameters of TGF- $\beta 1$ content in platelet-rich (PRP) and platelet-poor plasma (PPP) in patients with different pathologies of musculoskeletal system.

\begin{tabular}{|c|c|c|c|c|c|c|}
\hline PATIENT & DIAGNOSIS & AGE & GENDER & PRP SAMPLES & PPP, ng/ml & PRP, ng/ml \\
\hline 1 & Knee osteoarthritis & 57 & Female & 1 & 7.34 & 184.44 \\
\hline 2 & Meniscus injury & 39 & Male & 1 & 2.44 & 184.00 \\
\hline \multirow{3}{*}{3} & \multirow{3}{*}{ Knee osteoarthritis } & \multirow{3}{*}{77} & \multirow{3}{*}{ Male } & \multirow{3}{*}{3} & 3.59 & 210.72 \\
\hline & & & & & 6.13 & 206.27 \\
\hline & & & & & 9.60 & 200.57 \\
\hline \multirow{2}{*}{4} & \multirow{2}{*}{ Meniscus tear } & \multirow{2}{*}{25} & \multirow{2}{*}{ Male } & \multirow{2}{*}{2} & 6.27 & 214.90 \\
\hline & & & & & 6.79 & 211.70 \\
\hline \multirow{2}{*}{5} & \multirow{2}{*}{ Torn foot ligament } & \multirow{2}{*}{21} & \multirow{2}{*}{ Female } & \multirow{2}{*}{2} & 3.94 & 224.63 \\
\hline & & & & & 3.59 & 220.46 \\
\hline \multirow{2}{*}{6} & \multirow{2}{*}{ Knee osteoarthritis } & \multirow{2}{*}{74} & \multirow{2}{*}{ Female } & \multirow{2}{*}{2} & 4.15 & 203.49 \\
\hline & & & & & 2.10 & 128.12 \\
\hline 7 & Tendinitis & 40 & Male & 1 & 10.20 & 156.63 \\
\hline 8 & $\begin{array}{l}\text { Non consolidated femoral } \\
\text { shaft fracture }\end{array}$ & 33 & Female & 1 & 6.86 & 213.23 \\
\hline 9 & Knee osteoarthritis & 79 & Female & 1 & 2.82 & 175.68 \\
\hline 10 & Knee osteoarthritis & 70 & Male & 1 & 8.49 & 219.35 \\
\hline \multirow{2}{*}{11} & \multirow{2}{*}{ Knee osteoarthritis } & \multirow{2}{*}{29} & \multirow{2}{*}{ Female } & \multirow{2}{*}{2} & 15.76 & 221.15 \\
\hline & & & & & 11.24 & 138.40 \\
\hline 12 & $\begin{array}{l}\text { Osteoarthritis of the phalangeal } \\
\text { joint of the foot }\end{array}$ & 31 & Female & 1 & 10.44 & 210.59 \\
\hline 13 & Knee osteoarthritis & 65 & Female & 1 & 3.21 & 205.58 \\
\hline 14 & Meniscus tear & 48 & Male & 1 & 9.53 & 204.47 \\
\hline
\end{tabular}




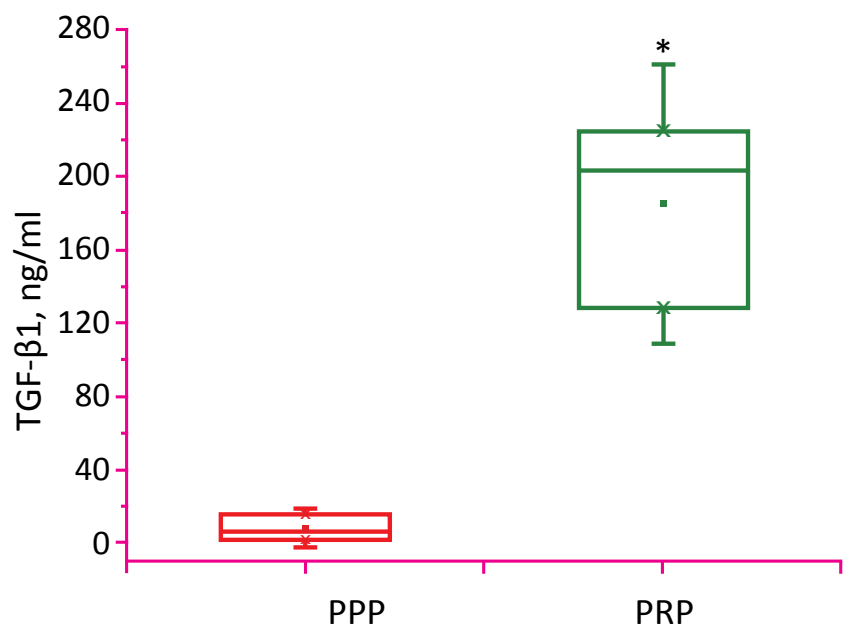

Fig. 1. The average level of TGF- $\beta 1$ in test samples of platelet-rich plasma (PRP) and platelet-poor plasma (PPP); $p<0.05$

treatment [26, 27]. TGF- $\beta 1$ enhances cartilage cell proliferation and extracellular matrix synthesis [24]. It also contributes to the chondrogenic differentiation of mesenchymal stem cells in vitro $[23,28]$. TGF- $\beta 1$ promotes the proliferation of tendon fibroblasts and their synthesis of extracellular matrix, in particular collagen type I, etc. $[8,16]$, which can help to restore tendons after injuries. This growth factor, also involved in the regulation of tissue repair [29], in particular TGF- $\beta 1$, promotes healing of bone fractures, involving bone marrow stem cells at the site of injury $[7,22]$. Therefore, TGF- $\beta 1$ can be used to treat a variety of disorders of the musculoskeletal system while PRP serves as a source for therapeutic purposes.

No statistically significant difference was found between TGF- $\beta 1$ level in PRP in the patients of different genders $(p=0.4)$, which is consistent with the literature data $[25,30,31]$. In women, the content of cytokine was $207.13 \pm 16.28 \mathrm{ng} / \mathrm{ml}$, and in men $196.36 \pm 22.42 \mathrm{ng} / \mathrm{ml}$ (Fig. 2).

The level of TGF- $\beta 1$ was investigated in patients' PRP, depending on their age without taking into account gender, since no significant difference was found between the content of TGF- $\beta 1$ and gender in the samples. We did not find any dependence of TGF- $\beta 1$ content in plateletenriched plasma on patients' age ( $p>0.008)$.

Data on the dependence of TGF- $\beta 1$ content in PRP on the age are quite contradictory. Some studies showed that the content of TGF- $\beta 1$ in PRP does not depend on the age of the studied patients $[25,30]$ Whereas, J. Evanson et al. found that people up to 25 years old had higher cytokine levels in PRP than those of older age groups [31].

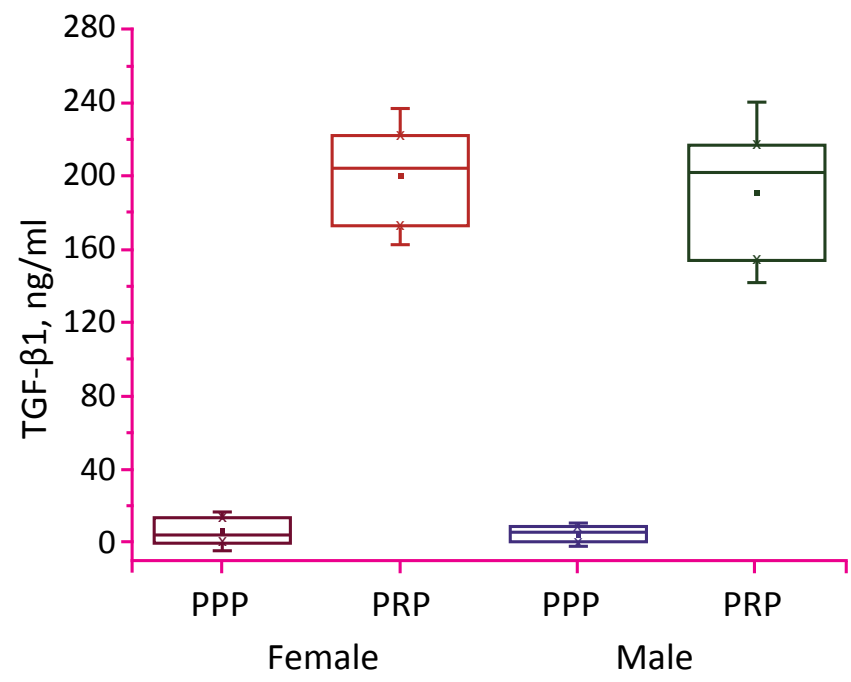

Fig. 2. TGF- $\beta 1$ content in platelet-rich plasma (PRP) and platelet-poor plasma (PPP) depending on the gender of the patients; $p=0.4$.

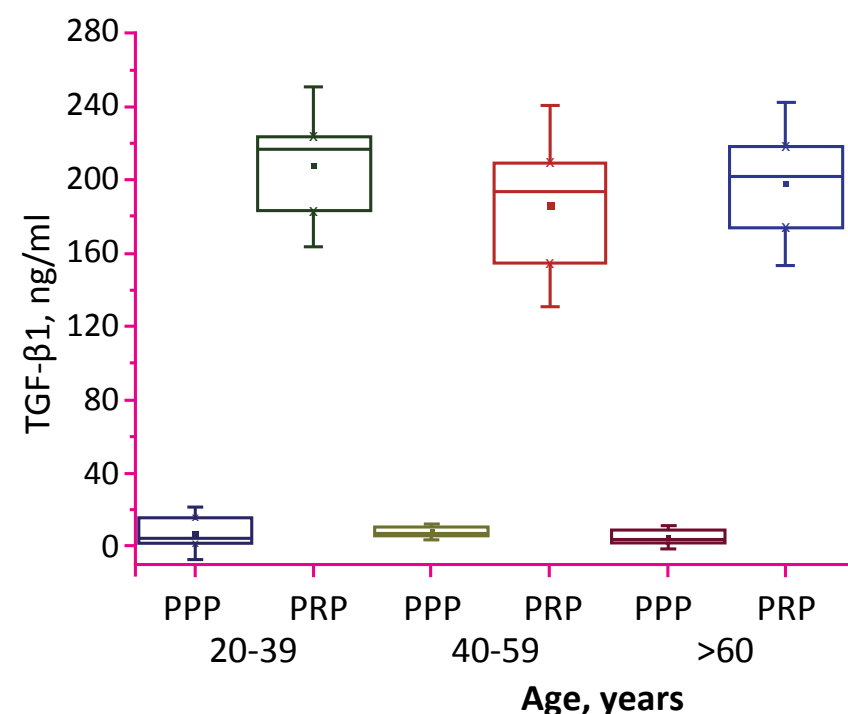

Fig. 3. TGF- $\beta 1$ content of platelet-rich plasma (PRP) and platelet-poor plasma (PPP) in different age groups of patients; $p>0.008$.

\section{CONCLUSION}

1. In the study of TGF- $\beta 1$ content in platelet-rich plasma, it was shown that its level was 30 times higher than in the control plateletpoor plasma samples. No statistically significant difference was found between TGF- $\beta 1$ levels in platelet-rich plasma between different genders. No dependence of TGF- $\beta 1$ content in platelet-rich plasma on patient age was found.

2. 2. In vitro study determined that platelet-rich plasma can serve as a source of TGF- $\beta 1$ for the treatment of various diseases of the musculoskeletal system. In this study, it was shown that the content of TGF- $\beta 1$ in platelet-rich plasma was independent of the gender and age of the examined patients, and therefore may be recommended for use in a wide range of patients.

\section{REFERENCES}

1. Alsousou J, Thompson M, Hulley P. The biology of platelet-rich plasma and its application in trauma and orthopaedic surgery. J Bone Joint Surg. 2009; 91(8):987-996. DOI: $10.1302 / 0301-620 X .91 B 8.22546$.

2. Alves R, Grimalt R. A review of platelet-rich plasma: History, Biology, mechanism of action, and classification. Skin Appendage Disord. 2018; 4(1):18-24. D0I: $10.1159 / 000477353$ 
3. Anitua E, Orive G. Clinical outcome of immediately loaded dental implants bioactivated with plasma rich in growth factors: a 5-year retrospective study. J Periodontol. 2008; 79(7): 1168-1176. DOI:10.1902/jop.2010.090637.

4. Araki J, Jona M, Eto H. Optimized preparation method of platelet-concentrated plasma and noncoagulating plateletderived factor concentrates: maximization of platelet concentration and removal of fibrinogen. Tissue Eng Part C Methods. 2012; 18(3):176-85. DOl: 10.1089/ten.TEC.2011.0308.

5. Assirelli E, Filardo G. Effect of two different preparations of platelet-rich plasma on synoviocytes. Knee Surg Sports Traumatol Arthrosc. 2015; 23(9):2690-2703. D0I: 10.1007/s00167-014-3113-3.

6. van Beuningen HM, van der Kraan PM, Arntz OJ, van den Berg WB. Does TGF-beta protect articular cartilage in vivo? Agents Actions Suppl. 1993; 39:27-131. DOI:10.1007/978-3-0348-7442-7_14.

7. Crane JL, Xian L, Cao X. Role of TGF- $\beta$ signaling in coupling bone remodeling. Methods Mol Biol. 2016; 1344:287-300. DOl:10.1007/978-1-4939-2966-5_18.

8. Dahlgren LA, Mohammed HO, Nixon AJ. Temporal expression of growth factors and matrix molecules in healing tendon lesions. J Orthop Res. 2005; 23(1):84. https:// doi.org/10.1016/j.orthres.2004.05.007.

9. Dawood AS, Salem HA. Current clinical applications of platelet-rich plasma in various gynecological disorders: An appraisal of theory and practice. Clin Exp Reprod Med. 2018; 45(2):67-74. DOI: 10.5653/cerm.2018.45.2.67.

10. Dhillon RS, Schwarz EM, Maloney MD. Platelet-rich plasma therapy - future or trend? Arthritis Res Ther. 2012; 14(4):219-229. D0l: $10.1186 / a r 3914$.

11. Dohan Ehrenfest DM, Rasmusson L. Classification of platelet concentrates: from pure platelet-rich plasma (P-PRP) to leucocyte- and platelet-rich fibrin (L-PRF). Trends Biotechnol. 2009; 27(3):158-167. DOl: 10.1016/j.tibtech.2008.11.009.

12. Elghblawi E. Platelet-rich plasma, the ultimate secret for youthful skin elixir and hair growth triggering. J Cosmet Dermatol. 2018; 17(3):423-430. D0l: 10.1111/ jocd.12404.

13. El-Sharkawy H, Kantarci A, Deady J. Platelet-rich plasma: growth factors and pro- and anti-inflammatory properties. J Periodontol. 2007; 78(4):661-669. DOI: 10.1902/ jop.2007.060302.

14. Eppley BL, Pietrzak WS, Blanton M. Platelet-rich plasma: a review of biology and applications in plastic surgery. Plast Reconstr Surg. 2006; 118(6):147-159. D0I: 10.1097/01.prs.0000239606.92676.cf.

15. Eppley BL, Woodell JE, Higgins J. Platelet quantification and growth factor analysis from platelet-rich plasma: implications for wound healing. Plast Reconstr Surg. 2004; 114(6): 1502-1508. DOI: 10.1097/01.prs.0000138251.07040.51.

16. Gumucio JP, Sugg KB, Mendias CL. TGF- $\beta$ superfamily signaling in muscle and tendon adaptation to resistance exercise. Exerc Sport Sci Rev. 2015; 43(2):93-99. DOI: 10.1249/JES.0000000000000041.

17. James $A W, X u Y$, Lee $J K$, Wang $R$. Differential effects of TGF-beta1 and TGF-beta 3 on chondrogenesis in posterofrontal cranial suture-derived mesenchymal cells in vitro. Plast Reconstr Surg. 2009; 123(1):31-43. D0l: 10.1097/PRS.0b013e3181904c19.

18. Klatte-Schulz F, Schmidt T, Uckert M. Comparative Analysis of Different Platelet Lysates and Platelet Rich Preparations to Stimulate Tendon Cell Biology: An In Vitro Study. Int J Mol Sci. 2018; 19(1):1-18. DOl: 10.3390/ijms19010212.

19. van der Kraan PM. TGF-beta signaling in chondrocyte terminal differentiation and osteoarthritis. Osteoarthritis and Cartilage. 2009; 17(12):1539-1545. DOI: 10.1016/j. joca.2009.06.008.

20. Magalon J, Chateau AL. DEPA classification: a proposal for standardising PRP use and a retrospective application of available devices. BMJ Open Sport Exerc Med. 2016; 2(1):1-5. DOI: 10.1136/bmjsem-2015-000060.

21. Perut $F$, Filardo G. Preparation method and growth factor content of platelet concentrate influence the osteogenic differentiation of bone marrow stromal cells. Cythotherapy. 2013; 15(7):830-839. D0l: 10.1016/j.jcyt.2013.01.220.

22. Poniatowski LA, Wojdasiewicz $P$, Gasik $R$. Transforming growth factor beta family: insight into the role of growth factors in regulation of fracture healing Biology and potential clinical applications. Mediators Inflamm. 2015; 2015:1-15. DOl: 10.1155/2015/137823.

23. Tuli $R$, Tuli $S$, Nandi $S$, Huang $X$. Transforming growth factor- -mediated chondrogenesis of human mesenchymal progenitor cells involves $\mathrm{N}$-cadherin and mitogenactivated protein kinase and Wnt signaling cross-talk. J Biol Chem. 2003; 278(42):41227-41236. DOI: 10.1074/jbc.M305312200.

24. Wang W, Rigueur D, Lyons KM. TGFß Signaling in Cartilage Development and Maintenance. Birth Defects Res C Embryo Today. 2014; 102(1):37-51. DOI: 10.1002/ jbmr.3394.

25. Weibrich G, Kleis, WK, Hafner G. Growth factor levels in platelet-rich plasma and correlations with donor age, sex, and platelet count. J Craniomaxillofac Surg. 2002; 30(2):97-102. DOI: 10.1054/jcms.2002.0285.

26. Cherian JJ, Parvizi J. Preliminary results of a phase II randomized study to determine the efficacy and safety of genetically engineered allogeneic human chondrocytes expressing TGF- $\beta 1$ in patients with grade 3 chronic degenerative joint disease of the knee Osteoarthritis Cartilage. 2015; 23(12):2109-2118. D0l: 10.1016/j. joca.2015.06.019.

27. Lee MC, Ha CW, Elmallah RK A placebo-controlled randomised trial to assess the effect of TGF- $\beta 1$-expressing chondrocytes in patients with arthritis of the knee.Bone Joint J. 2015; 97B(7):924-932. DOI: 10.1302/0301-620X.97B7.35852.

28. Fang $D$, Jin $P$, Huang $Q$. Platelet-rich plasma promotes the regeneration of cartilage engineered by mesenchymal stem cells and collagen hydrogel via the TGF- $\beta / S M A D$ signaling pathway. J Cell Physiol. 2019; 234(9):15627-15637 DOl: 10.1002/jcp.28211

29. Tang Y, Wu X, Lei W, Pang L. TGF-beta1-induced migration of bone mesenchymal stem cells couples bone resorption with formation. Nat Med. 2009; 15(7):757-65. DOI: $10.1038 / \mathrm{nm} .1979$.

30. Taniguchi $Y$, Yoshioka $T$. Growth factor levels in leukocyte-poor platelet-rich plasma and correlations with donor age, gender, and platelets in the Japanese population I. Journal of Experimental Orthopaedics. 2019; 6:4. DOI: 10.1186/s40634-019-0175-7.

31. Evanson JR, Guyton MK., Gender and age differences in growth factor concentrations from platelet-rich plasma in adults. Mil Med. 2014; 179(7):799-805. D0I: 10.7205/MILMED-D-13-00336.

\begin{tabular}{|c|c|}
\hline TRTICL ON THE SITE \\
\hline
\end{tabular}

The authors declared no potential conflicts of interest with respect to the research, authorship, and/or publication of this article.

Received: October 30, 2019

Accepted: November 30, 2019 